\title{
Effect of the structure of $o, o^{\prime}$-dihydroxyazo compounds on bactericidal and inhibitory ability
}

\author{
V.I. Vigdorovich, ${ }^{1}$ A.N. Zavershinskii, ${ }^{2}$ L.E. Tsygankova, ${ }^{2}$ T.N. Nazina, ${ }^{3}$ \\ M.N. Esina ${ }^{2}$ and N.V. Shel ${ }^{4}$ \\ ${ }^{1}$ All-Russian Scientific Research Institute of Use of Machinery and Oil Products, \\ 392022 Tambov, Russia \\ ${ }^{2}$ Derzhavin State University, ul. Internatsyonalnaya, 33, 392000 Tambov, \\ Russian Federation \\ ${ }^{3}$ Winogradsky Institute of Microbiology, Russian Academy of Sciences, Leninsky prosp., \\ 33, bldg. 2, 119071 Moscow, Russian Federation \\ ${ }^{4}$ Tambov State Technical University, ul. Sovetskaya, 106, 392000 Tambov, \\ Russian Federation \\ E-mail:vits21@mail.ru
}

\begin{abstract}
The paper is devoted to a study of the influence of the molecule structure of a number of $o, o^{\prime}$ - dihydroxyazo (DHA) compounds on their bactericidal ability toward sulfate-reducing bacteria (SRB) in the Postgate medium at small concentrations (5-20 mg/L). DHA compounds induce a decrease in number of bacterial cells, $\mathrm{H}_{2} \mathrm{~S}$ production by SRB, and hydrogen permeation into carbon steel in the presence of SRB. The inhibition of steel corrosion in the bacterial medium by these substances is considered as well.
\end{abstract}

Key words: carbon steel, microbiological corrosion, weight loss, hydrogen permeation, polarization, bactericide, inhibitor, structure, bacteria.

Received: October 30, 2016. Published: December 12, 2016.

doi: $\underline{10.17675 / 2305-6894-2017-6-1-1}$

\section{Introduction}

The adverse effect of microbiological corrosion on structural metals is so great [1] and their damage to the world economy is so huge [2] that the problems of struggle against it are constantly in the field of vision of the researches [3-15]. Moreover, 20\% of all losses from corrosion are due to microbiological impact.

In most cases, studies deal with the effects of sulfate-reducing bacteria $[6,9,11,12]$. However, stimulation of the corrosion of metals, particularly steel, zinc, and galvanized steel $[12,13]$ by other microorganisms (Esteria Coli, Proteus vulgaris, Pseudomonasaeruginosa, Brucella sp, Gallionella sp, Staphylococus aureus, Staphylococus epidermidis $[7,13])$ is considered as well. More frequently, the stimulating effect of bacteria cells, in particular SRB, is interpreted as the result of acceleration of the cathodic reaction because of accumulation of micro organism vital activity products, primarily hydrogen sulfide 
$[5,16]$. However, the possibility of substantial change in the nature of electrochemical reactions [9] and electron transfer in the electrode processes [11] is sufficiently broadly discussed. Serious attention is paid to studies of biofilm formation processes based on micro organism colonies and their screening influence [10] or accumulation of corrosion stimulators near a corroding surface [17].

It has been shown that in a number of cases, films of live micro organisms induce corrosion retardation and prevent pitting formation [14]. Death of microorganisms on exposure to antibiotics (penicillin, neomycin) induces a decrease in polarization resistance and corrosion potential of steel and a growth in the corrosion rate, or depassivation of aluminum in model sea water.

Hydrogen sulfide produced by sulfate-reducing bacteria (SRB) promotes the formation of a polysulfide film of corrosion products on the metal surface. This film often has certain protective properties and leads to a significant decrease in corrosion rate [18-22]. This effect becomes stronger in the presence of an inhibitor [23-25]. In the presence of SRB it has been shown that "there is no indication for significant catalytic enhancement of the abiotic cathodic proton reduction to hydrogen by deposited ferrous sulfide crusts" [11]. Thus, SRB can render both positive and negative effects on development of corrosion processes. The first effect prevails under certain conditions, and the second one prevails under others.

The present paper is devoted to a study of the effect of the molecular structure of $o, o^{\prime}$ - dihydroxyazo compounds on their bactericidal and inhibiting ability under conditions of carbon steel corrosion in the presence of SRB. This allows one to determine the direction of synthesis of inhibitors-bactericides efficient in small concentrations.

\section{Experimental}

\subsection{Chemicals and organisms}

All solutions and culture media were prepared from chemicals of analytical grade and distilled water. Sulfate-reducing bacterium strain Luk used in this study was phylogenetically closed (99\% similarity of $16 \mathrm{~S}$ rRNA genes) to the type strain Desulfomicrobium apsheronum $1105^{\mathrm{T}}$ isolated from a petroleum reservoir [26].

The culture liquid was sterilized at $121^{\circ} \mathrm{C}$ for $45 \mathrm{~min}$, cooled to $35^{\circ} \mathrm{C}$, and inoculated with the SRB culture resulting in an initial concentration of $10^{6}$ cells per $\mathrm{cm}^{3}$. The test system was incubated at $32^{\circ} \mathrm{C}$ for $168 \mathrm{~h}$ until completion of the vital cycle of the microorganisms (Figure 1) [27]. The vital cycle of the microorganisms can be divided into several distinct phases called the lag phase, exponential phase, stationary phase and death phase. 


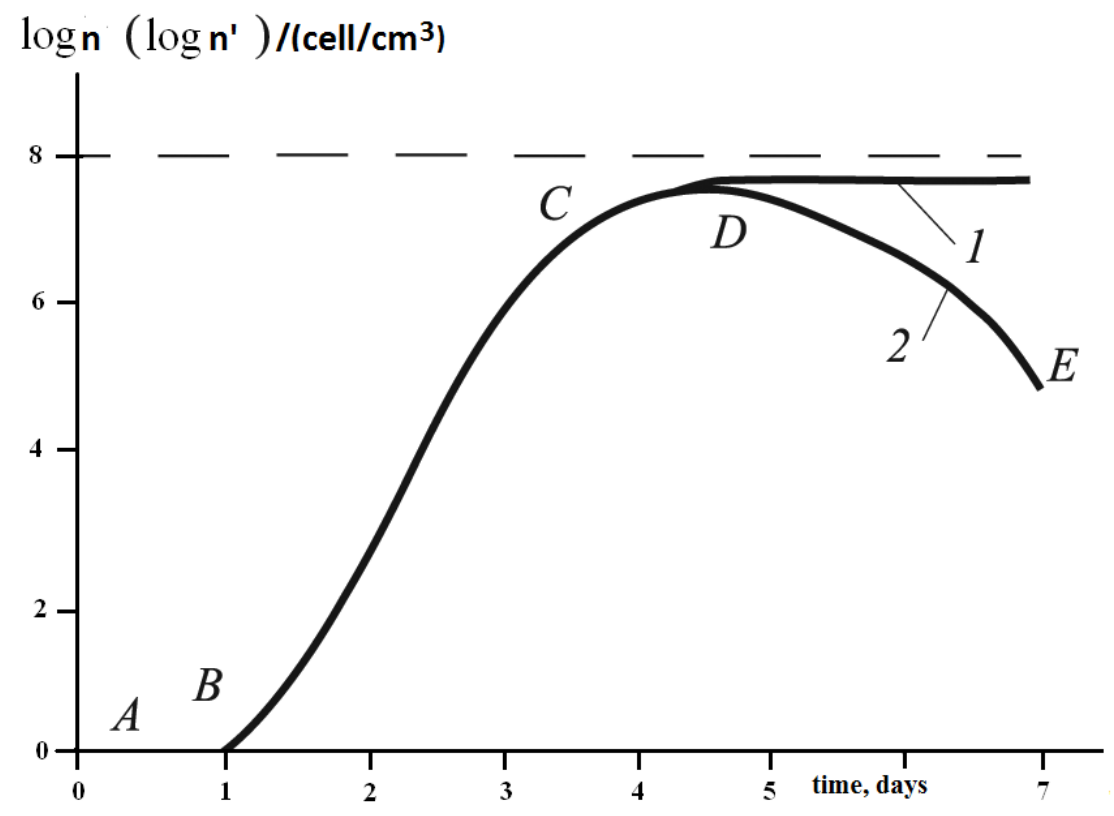

Figure 1. A typical bacterial growth curve. $n(1)$ and $n^{\prime}(2)$ are the total number of cells and the number of viable ones, respectively. $\mathrm{AB}$ is the lag phase, $\mathrm{BC}$ is the exponential phase, $\mathrm{CD}$ is the stationary phase, and DE is the death phase.

Postgate medium $\mathrm{B}$ with the composition, g/L: $\mathrm{NH}_{4} \mathrm{Cl}-1.0 ; \mathrm{K}_{2} \mathrm{HPO}_{4}-0.5$; $\mathrm{MgSO}_{4} \cdot 7 \mathrm{H}_{2} \mathrm{O}-2.0 ; \mathrm{Na}_{2} \mathrm{SO}_{4}-0.5 ; \mathrm{CaCl}_{2}-0.1 ;$ calcium lactate -3.5 ; yeast extract -1 [28] was used as the culture liquid. The number of sulfate-reducing bacteria was counted by a method called the direct microscopic count. A special counting chamber was used. In such a counting chamber, a grid is marked on the surface of the glass slide with squares of a known small area. The number of cells per $\mathrm{cm}^{3}(n)$ is calculated by the formula

$$
n=1000 \mathrm{a} / \mathrm{hS} \text {, }
$$

where $a$ is the average number of cells in a grid square, $h$ is the depth of the chamber $(\mathrm{mm})$, and $S$ is the area of the grid square $\left(\mathrm{mm}^{2}\right)$.

The biogenic $\mathrm{H}_{2} \mathrm{~S}$ concentration was determined daily by iodometric titration. $o, o^{\prime}-$ Dihydroxyazo (DHA) compounds (Table 1) were used as inhibitors and bactericides. Their concentrations were varied from 5 to $20 \mathrm{mg} / \mathrm{L}$. 
Table 1. Structural formulae of $o, o^{\prime}$-dihydroxyazo compounds.

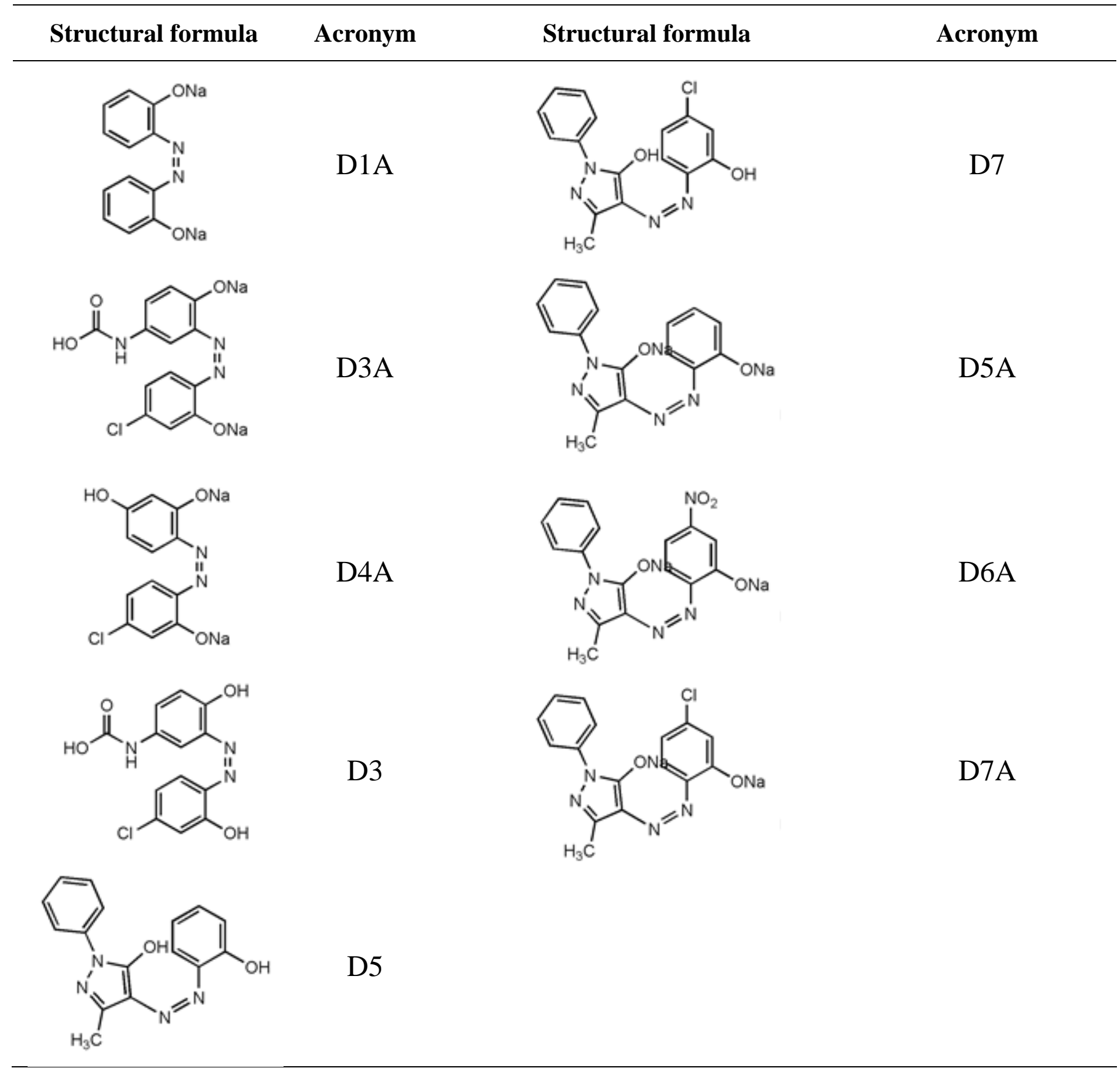

\subsection{Corrosion tests}

The corrosion tests of carbon steel samples were carried out by the weight loss method in the inoculated Postgate media without and with DHA compounds $(5-20 \mathrm{mg} / \mathrm{L})$ on steel plates with dimensions of $10 \times 60 \times 2 \mathrm{~mm}$. The chemical composition (mass \%) of the carbon steel used was: $\mathrm{C}-0.20 ; \mathrm{Mn}-0.50 ; \mathrm{Si}-0.15 ; \mathrm{P}-0.04 ; \mathrm{Cr}-0.30 ; \mathrm{Ni}-0.20 ; \mathrm{Cu}-0.20$; Fe balance. The tests lasted for $24-168 \mathrm{~h}$ at $32^{\circ} \mathrm{C}$. 
The surfaces of the working electrodes were ground with emery papers of various roughness, degreased with acetone, rinsed with bi-distilled water, and dried with filter paper. Before corrosion tests, the samples were weighed.

After testing, the sample surface was cleaned from corrosion products, washed with bi-distilled water, degreased with acetone, and re-weighed to determine the weight loss.

The inhibitor protective effect $(Z, \%)$ was calculated by the following equation:

$$
Z=\left(K_{0}-K_{i}\right) \cdot 100 / K_{0},
$$

where $K_{0}$ and $K_{i}$ are the corrosion rates in the non-inhibited and inhibited solutions, respectively.

\subsection{Determination of bactericidal efficiency of DHA compounds}

DHA compounds $(5-20 \mathrm{mg} / \mathrm{L})$ were added to the inoculated Postgate media incubated at $32^{\circ} \mathrm{C}$. Measurements of biogenic $\mathrm{H}_{2} \mathrm{~S}$ concentration and total cell count were conducted daily for $168 \mathrm{~h}$. The results were compared with those in the media without DHA compounds.

The coefficient of microorganism suppression by the bactericide $(\rho, \%)$ was calculated according to the formula:

$$
\rho(\%)=10^{2} \cdot\left(n_{0}-n\right) / n_{0},
$$

where $n_{0}$ and $n$ are the cell (volume) density in the background solution and in the inhibited one, respectively.

\subsection{Electrochemical diffusion method for the estimation of hydrogen permeation into the metal}

For estimation of hydrogen permeation into the metal, a two-chamber cell with a vertical steel membrane (Figure 2) similar to the Devanathan cell [29, 30] was used. Carbon steel membrane with an exposed area of $3.63 \mathrm{~cm}^{2}$ and a thickness of $300 \mu \mathrm{m}$ was used. Both faces of the membrane were mechanically abraded using different grades of sand papers, cleaned by washing with distilled water, acetone, and bi-distilled water respectively and dried with filter paper. For each test, a freshly abraded surface was used. The entrance side of the membrane contacted with the working solution. The exit side of the membrane contacted with a titrated permanganate solution, which completely oxidized hydrogen diffused across the membrane. The hydrogen diffusion flux $\left(i_{\mathrm{H}}\right)$ was estimated from the decrease in permanganate concentration $[31,32]$. The measurements were conducted at the corrosion potential and under cathodic and anodic polarization of the entrance membrane side. The duration of the permeation experiment was 2-8 hours. Potentiostatic anodic and cathodic polarization of the entrance membrane side was made with a Pt auxiliary electrode. The potentials were measured relative to an aqueous saturated silver/silver chloride electrode and converted to the standard hydrogen electrode (SHE) scale. 


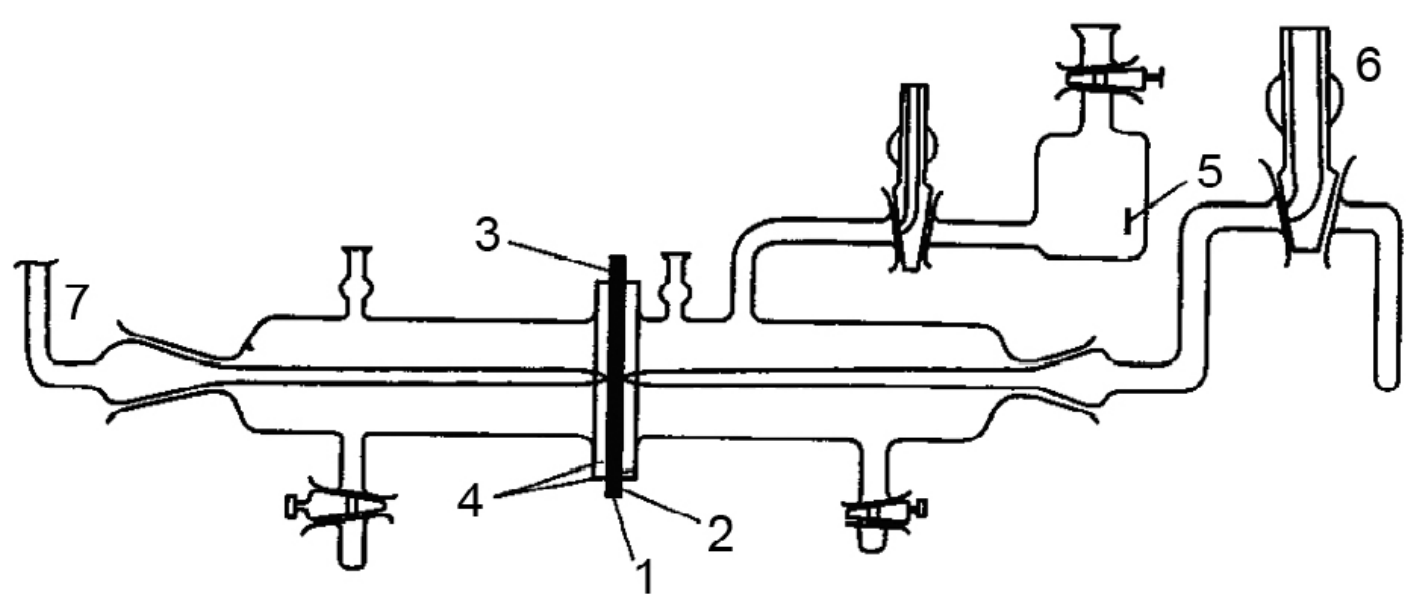

Figure 2. The Devanathan type cell. 1 - steel membrane, 2 - entrance side of the membrane, 3 - exit side of the membrane, 4 - fluoroplastic washer, 5 - Pt auxiliary electrode, 6 - the electrolytic contact between the Luggin capillary and the reference electrode, 7 - Luggin capillary.

For estimation of the suppression of the hydrogen diffusion flux through the membrane by the inhibitor, the coefficient

$$
\gamma=i_{0, \mathrm{H}} / i_{\mathrm{H}}
$$

was used, where $i_{0, \mathrm{H}}$ and $i_{\mathrm{H}}$ are the hydrogen diffusion fluxes through the steel membrane in the uninhibited and inhibited solutions, respectively. Values of $\gamma>1$ correspond to a suppression of hydrogen permeation, whereas $\gamma<1$ values correspond to its stimulation.

\section{Results and discussion}

\subsection{Effect of o, $o^{\prime}$-dihydroxyazo compounds on SRB quantity}

D1A compound with - ONa substituents in the phenyl rings of the molecule practically does not affect the SRB quantity at the beginning of the exponential phase and throughout the entire phase of microorganisms death (Figure 3a). Only at the stationary phase, a reliable decrease in the number of bacterial cells by $21 \%$ is observed $(20 \mathrm{mg} / \mathrm{L} \mathrm{D} 1 \mathrm{~A})$. The effect of D3A inhibitor (the additional substituents in the phenyl rings are $-\mathrm{Cl}$ and 5'$\mathrm{NHCOOH}$ ) was noticeably stronger (Figure 3c). A reliable decrease in microorganism quantity is observed in all the phases of SRB vital cycle at the inhibitor concentrations studied.

Thus, the presence of a $\mathrm{Cl}$ atom and a $5^{\prime}-\mathrm{NHCOOH}$ group in the benzene ring appreciably increases the bactericidal action of the compound.

Comparison of the structures of D3 and D3A molecules gives an opportunity to evaluate the effect of replacement of hydroxy groups in the benzene rings with - ONa 
groups on the change in bactericidal ability (Figure $3 b, c)$. One can see that the effect is significant (Table 2).
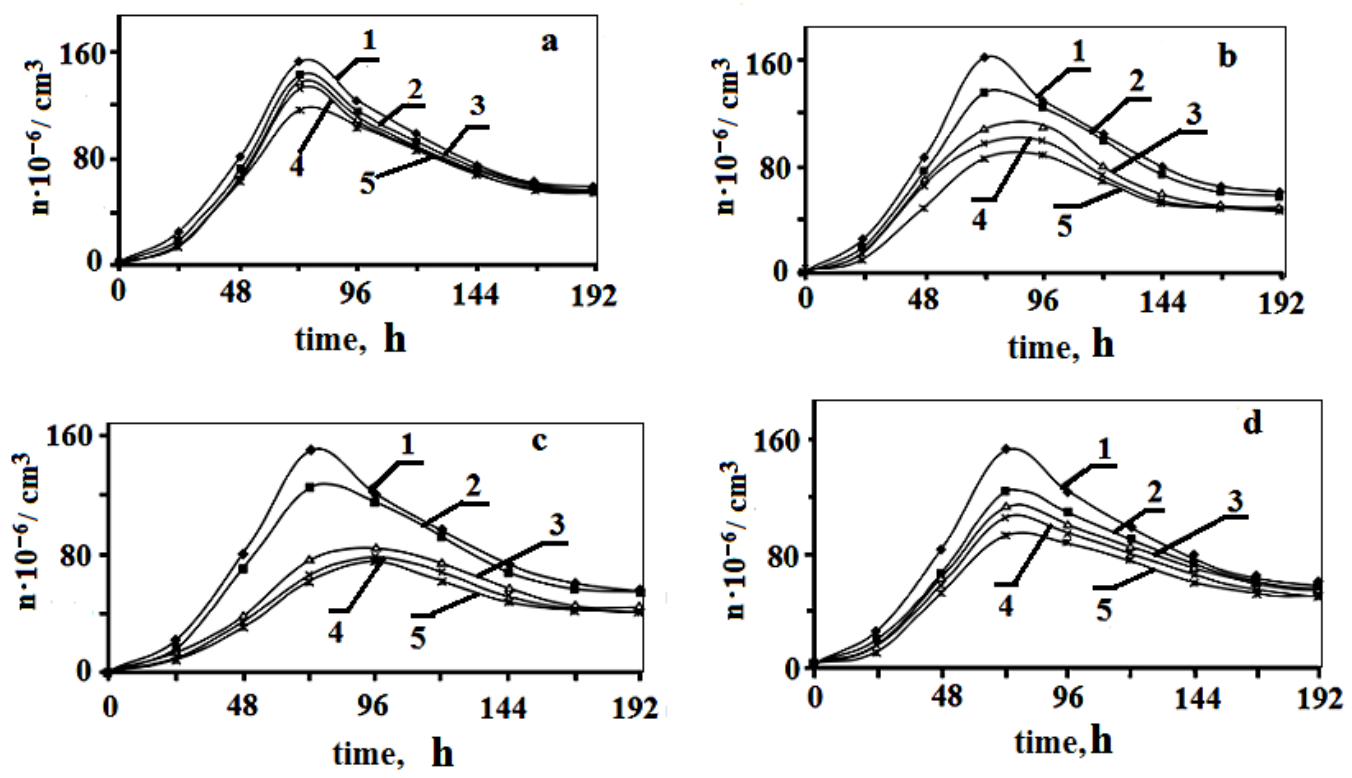

Figure 3. Change of SRB quantity $\left(n / \mathrm{cm}^{3}\right)$ in time in the process of their development in the Postgate medium without (1) and with DHA compounds (2-5), mg/L: $2-5 ; 3-10 ; 4-15$; 5 - 20. a - D1A; b - D3; c - D3A, d - D4A.

Table 2. Effect of the nature and concentration of the DHA compounds on the coefficient of microorganism suppression $(\rho, \%)$ in the stationary phase of SRB vital cycle.

\begin{tabular}{ccccc}
\hline Bactericide & \multicolumn{4}{c}{$\boldsymbol{\rho}, \mathbf{\%} \mathbf{a t} \mathbf{C}_{\mathbf{D H A}}, \mathbf{m g} \mathbf{\mathbf { L }}$} \\
\hline & 5 & 10 & 15 & 20 \\
D1A & 5 & 10 & 16 & 21 \\
D3 & 17 & 38 & 42 & 49 \\
D3A & 17 & 52 & 60 & 61 \\
D4A & 20 & 30 & 33 & 42 \\
D5 & 36 & 45 & - & - \\
D5A & 35 & 47 & - & - \\
D6A & 45 & 63 & 68 & 70 \\
D7 & 63 & 77 & 80 & 88 \\
D7A & 73 & 87 & 90 & 93 \\
\hline
\end{tabular}

D4A shows a lower bactericidal ability than D3A because of the presence of $4^{\prime}-\mathrm{OH}$ instead of $5^{\prime}-\mathrm{NHCOOH}$ in the benzene ring of the molecule (Table 2). 
Comparison of the bactericidal action of D3 (Figure 3b) and D5 (Figure 4a) permits one to estimate the replacement of one phenyl ring (D3) by a more complicated 1-phenyl3-methylpyrazole group (D5). This change does not lead to marked change in the bactericidal effect. The same result is shown by D5A where, in contrast to D5, $-\mathrm{ONa}$ groups are present in the molecule instead of the initial $-\mathrm{OH}$ groups (Table 2). Furthermore, D5 and D5A are characterized by small solubility that does not exceed $10 \mathrm{mg} / \mathrm{L}$. Perhaps, the absence of a $-\mathrm{NHCOOH}$ substituent in the phenyl ring of the D5 and D5A molecules affects their solubility.

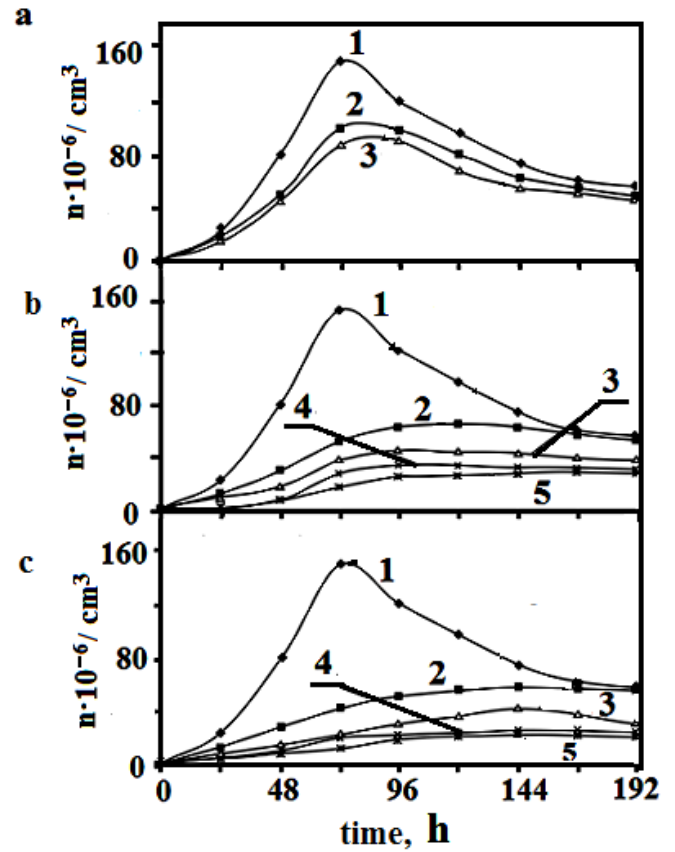

Figure 4. Change in SRB quantity $\left(n / \mathrm{cm}^{3}\right)$ vs. time in the course of bacteria development in the Postgate medium without ( 1 ) and with DHA compounds (2-5), $\mathrm{mg} / \mathrm{L}: 2-5 ; 3-10 ; 4-$ $15 ; 5-20 . a-\mathrm{D} 5 ; b-\mathrm{D} 7 ; c-\mathrm{D} 7 \mathrm{~A}$.

It is interesting to compare the effect of D5A and D6A (Table 2), where a nitro group is present as a substituent in the benzene ring. A certain increase in the bactericidal ability of D6A is observed. The presence of an $\mathrm{NO}_{2}$ group in the benzene ring results in an increase in the D6A solubility. The presence of a $\mathrm{Cl}$ atom in the benzene ring as a substituent (D7) increases the solubility and bactericidal properties in comparison with D5 (Table 2).

D7A compound containing, in contrast to D7, -ONa groups instead of $-\mathrm{OH}$ groups, shows highest bactericidal effect (Table 2). The bactericidal ability of D7A is higher than that of D6A because of replacement of the $\mathrm{NO}_{2}$ group by a $\mathrm{Cl}$ atom in the benzene ring.

One can see the absence of the exponential phase in the SRB vital cycle in the presence of D7 and D7A compounds (Figure 4b,c). Thus, replacement of one benzene ring 
by a more complex 1-phenyl-3-methylpyrazole group in the DHA structure in the presence of such a substituent as $\mathrm{NO}_{2}$ or $\mathrm{Cl}$ in the other benzene ring leads to a growth in the bactericidal ability. At that, an increase in the bactericidal properties is observed with a change of the substituent nature in the benzene ring in the order $\mathrm{H}<\mathrm{NO}_{2}<\mathrm{Cl}$.

\subsection{Effect of o,o'-dihydroxyazo compounds on hydrogen sulfide production by SRB}

Accumulation of $\mathrm{H}_{2} \mathrm{~S}$ in the inoculated medium is observed during the first 72 hours of bacteria development (Figure 5). This is conditioned by the exponential growth of the SRB quantity. The maximum $\mathrm{H}_{2} \mathrm{~S}$ concentration is reached on the $3^{\text {rd }}$ day $(180-190 \mathrm{mg} / \mathrm{L})$ of SRB development in the absence of an inhibitor. After the highest level is reached (point $\mathrm{C}$ in Figure 5a), $\mathrm{H}_{2} \mathrm{~S}$ concentration slowly decreases and at the end of the SRB vital cycle it is about $120 \mathrm{mg} / \mathrm{L}$. One should not think that upon the death of the bacterial cells after completion of their vital cycle, the $\mathrm{H}_{2} \mathrm{~S}$ quantity will immediately decrease to zero. This is impossible because part of hydrogen sulfide does not undergo any transformations. Besides, the decrease in $\mathrm{H}_{2} \mathrm{~S}$ content is caused not only by the decrease of their numbers.
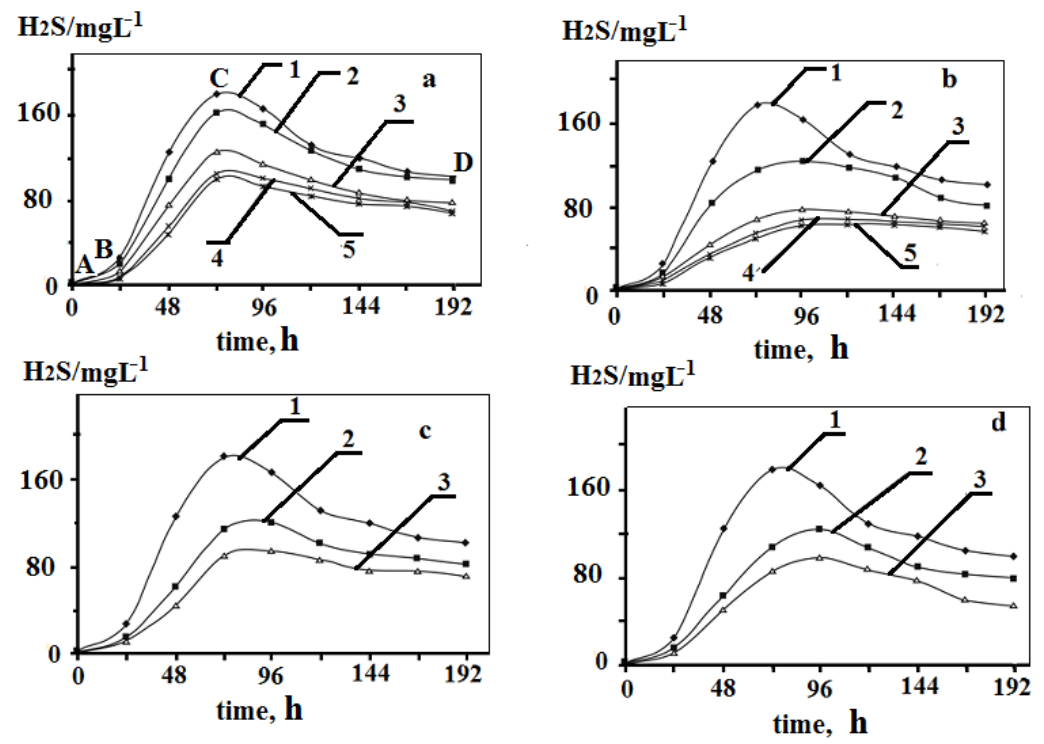

Figure 5. Change in biogenic $\mathrm{H}_{2} \mathrm{~S}$ concentration in time in the course of SRB development in the Postgate medium without (1) and with DHA compounds (2-5), mg/L: $2-5 ; 3-10 ; 4-$ $15 ; 5-20 . a-\mathrm{D} 1 \mathrm{~A} ; b-\mathrm{D} 3 ; c-\mathrm{D} 5 ; d-\mathrm{D} 5 \mathrm{~A}$.

Addition of $5 \mathrm{mg} / \mathrm{L}$ D1A insignificantly decreases $\mathrm{H}_{2} \mathrm{~S}$ formation. The maximum concentration of $\mathrm{H}_{2} \mathrm{~S}$ is $160 \mathrm{mg} / \mathrm{L}$ and after completion of the SRB vital cycle, it remains the same as in the absence of D1A. An increase in the D1A concentration to $10 \mathrm{mg} / \mathrm{L}$ leads to a more appreciable effect. In fact, the maximum $\mathrm{H}_{2} \mathrm{~S}$ concentration is $120 \mathrm{mg} / \mathrm{L}$ and at the end of the bacterial vital cycle it reaches $80 \mathrm{mg} / \mathrm{L}$ (point D in Figure 5a). A further 
growth in D1A concentration to $20 \mathrm{mg} / \mathrm{L}$ does not lead to a substantial decrease in $\mathrm{H}_{2} \mathrm{~S}$ formation (Figure 5a).

D3 inhibits $\mathrm{H}_{2} \mathrm{~S}$ production by SRB more effectively. For example, in the presence of $5 \mathrm{mg} / \mathrm{L} \mathrm{D} 3$, the maximum quantity of $\mathrm{H}_{2} \mathrm{~S}$ becomes $120 \mathrm{mg} / \mathrm{L}$, i.e., it decreases by $25 \%$ in comparison with the effect of the same quantity of D1A (Figure 5b, curve 2). But at the end of the bacterial vital cycle, $C\left(\mathrm{H}_{2} \mathrm{~S}\right)$ is practically the same as in the presence of D1A. A twofold increase in D3 concentration decreases the maximum $\mathrm{H}_{2} \mathrm{~S}$ concentration to $80 \mathrm{mg} / \mathrm{L}$ and at the end of the death phase - to $60 \mathrm{mg} / \mathrm{L}$. A further increase in D3 concentration has nearly no effect (Figure $5 b$ ).

Evidently, the effect of compounds of this series is not directed at the enzyme systems responsible for sulfate reduction. Otherwise, there would have been a significant drop in the concentration of hydrogen sulfide while maintaining a high number of bacterial cells. This conclusion is confirmed by the character of the effect of other $o, o^{\prime}$-dihydroxyazo compounds under study (Figures 5 and 6).

D5 does not appreciably change sulfate reduction by SRB in comparison with D3 (Figure 5). The same effect is also characteristic of D5A. A similar picture is observed in the suppression of the quantity of bacterial cells by these substances (Figure 4a). A clear correlation is observed for these effects of D5 and D5A products.

Replacement of an $\mathrm{H}$ atom in the phenyl radical (D5A) by a nitro group $-\mathrm{NO}_{2}$ (D6A) appreciably increases the effect of D6A in suppression of $\mathrm{H}_{2} \mathrm{~S}$ production by SRB. This effect is especially pronounced in the presence of $10 \mathrm{mg} / \mathrm{L}$ of these compounds (Figures $5 \mathrm{~d}$ and 6a). The same picture is observed with respect to the decrease in the quantity of bacteria under the influence of D5A and D6A. Thus, a reliable correlation exists between the changes in $n$ and $C\left(\mathrm{H}_{2} \mathrm{~S}\right)$ values. The presence of a $\mathrm{Cl}$ atom in the benzene ring of D7 molecule promotes the suppression of biogenic $\mathrm{H}_{2} \mathrm{~S}$ production in comparison with the effect of D5.

Let us compare the effects of D6A and D7A. Replacement of a nitro group $-\mathrm{NO}_{2}$ as a substituent in the benzene ring (D6A) by a $\mathrm{Cl}$ atom in D7A leads to further serious suppression of $\mathrm{H}_{2} \mathrm{~S}$ production in the presence of D7A (Figure 6a,b). This is especially expressed at $C_{\mathrm{DHA}} \geq 10 \mathrm{mg} / \mathrm{L}$ (Figure 6a,b, curves 4 and 5), although this effect is reliably observed even at a lower concentration of D6A and D7.

Finally, replacement of hydroxy groups in the benzene ring and imidazoline ring characteristic of D7 molecule by -ONa groups in D7A leads to a further decrease in biogenic $\mathrm{H}_{2} \mathrm{~S}$ concentration, other conditions being equal (Figure 6b,c). A decrease in $\mathrm{H}_{2} \mathrm{~S}$ formation is especially evident at $C_{\mathrm{D} 7 \mathrm{~A}} \geq 10 \mathrm{mg} / \mathrm{L}$. In fact, for example, at the end of the death phase of bacteria at $C_{\mathrm{DHA}}=15 \mathrm{mg} / \mathrm{L}, C\left(\mathrm{H}_{2} \mathrm{~S}\right)$ is $38 \mathrm{mg} / \mathrm{L}$ in the presence of D7 but $24 \mathrm{mg} / \mathrm{L}$ upon replacement of D7 with D7A (Figure 6b,c, curves 4). 


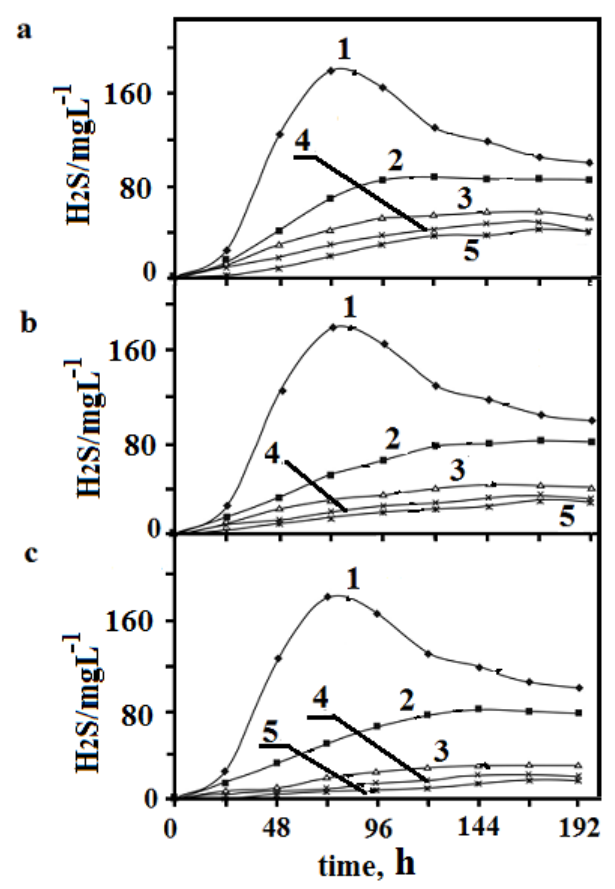

Figure 6. Change in biogenic $\mathrm{H}_{2} \mathrm{~S}$ concentration $v s$. time in the course of SRB development in the Postgate medium without ( 1 ) and with DHA compounds (2-5), mg/L: $2-5 ; 3-10 ; 4-15$; $5-20 . a-\mathrm{D} 6 \mathrm{~A} ; b-\mathrm{D} 7 ; c-\mathrm{D} 7 \mathrm{~A}$.

Moreover, yet another fact can be noticed. Whereas for D5 (Figure 5c) and D5A (Figure 5d) such a replacement of $\mathrm{OH}$ groups by $-\mathrm{ONa}$ groups does not influence the intensity of suppression of $\mathrm{H}_{2} \mathrm{~S}$ production by SRB, this takes place for D7 and D7A. The same picture is observed with respect to suppression of the number of bacterial cells (Figure $4 \mathrm{a}-\mathrm{c}$ ). One can see a mutual influence of the substituents in the benzene ring and 1-phenyl-3-methylpyrazole group. In this case, the presence of a $\mathrm{Cl}$ atom in the benzene ring increases the bactericidal ability in the direction from the $-\mathrm{OH}$ functional group (D7) to the -ONa group (D7A), i.e., a synergistic effect of the substituents is observed.

\subsection{Effect of DHA on the hydrogen diffusion flux through a membrane in the presence of $S R B$}

\subsubsection{Hydrogen diffusion flux at the corrosion potential of the membrane entrance side}

Bacterial cells in the process of their vital activity produce not only $\mathrm{H}_{2} \mathrm{~S}$ but also other substances that can stimulate the cathodic reactions leading to the appearance of adsorbed hydrogen $\left(\mathrm{H}_{\mathrm{ads}}\right)$ on the metal surface. This induces a hydrogen diffusion flux $\left(i_{\mathrm{H}}\right)$ into the metal. This is confirmed by the data of Figure 7 where one can see that the $i_{\mathrm{H}}$ value is substantially larger in the inoculated Postgate medium than in the sterile one $\left(C\left(\mathrm{H}_{2} \mathrm{~S}\right)\right.$ is the same in both cases and amounts to $190 \mathrm{mg} / \mathrm{L} . \mathrm{H}_{2} \mathrm{~S}$ was brought into the sterile Postgate medium from the outside). The dependence of $i_{\mathrm{H}}$ on time passes through a maximum in 
both cases. The presence of this maximum is caused by the formation of a polysulfide film on the steel surface in the course of time. Evidently, it begins to retard hydrogen permeation at a certain thickness.

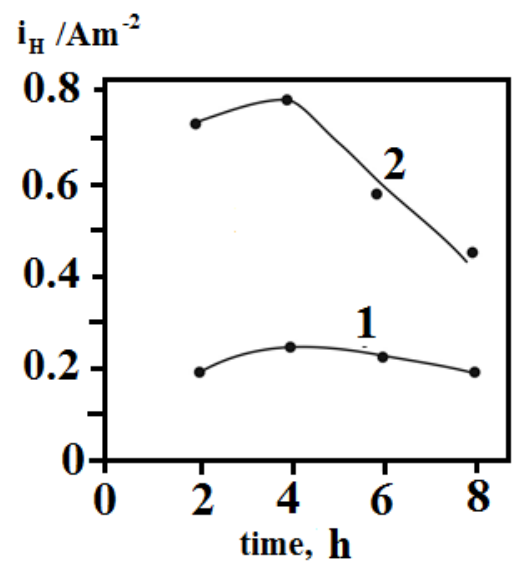

Figure 7. Influence of the experiment duration on the hydrogen diffusion flux $\left(i_{\mathrm{H}}\right)$ through the steel membrane at $E_{\text {corr }}$ in the sterile (1) and inoculated by SRB (2) nutrient Postgate medium containing $190 \mathrm{mg} / \mathrm{L} \mathrm{H}_{2} \mathrm{~S} .1-\mathrm{H}_{2} \mathrm{~S}$ was brought from outside; $2-\mathrm{H}_{2} \mathrm{~S}$ was produced by SRB.

The inhibitors under study decrease the hydrogen diffusion flux through the steel membrane in the presence of SRB. The largest decrease in $i_{\mathrm{H}}$ is caused by addition of D6A, D7, and D7A to the solution (Figure 8). As a rule, a higher efficiency is characteristic of substances whose molecules contain 1-phenyl-3-methylpyrazole group (D5, D5A, D6A, D7, D7A), especially if a $\mathrm{Cl}$ or nitro group are introduced as substituents into the benzene ring.

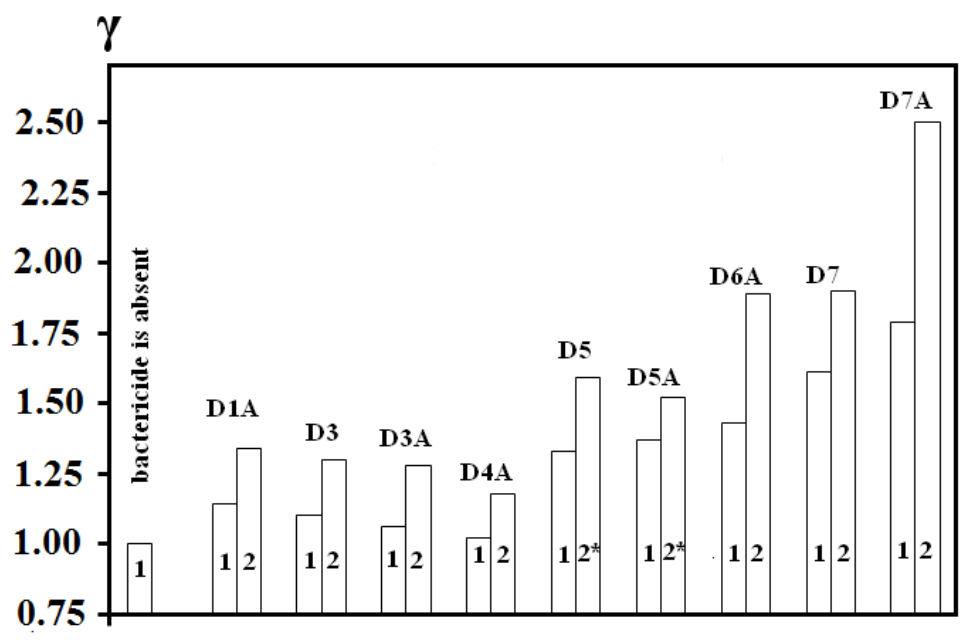

Figure 8. Effect of nature and concentration of the bactericides on $\gamma$ value in the Postgate medium containing $190 \mathrm{mg} / \mathrm{L} \mathrm{H}_{2} \mathrm{~S}$ inoculated by SRB. $C_{\mathrm{DHA}}, \mathrm{mg} / \mathrm{L}: 1-5 ; 2-20 ; 2^{*}-10$.

The SEM image of the membrane entrance side after the hydrogen permeation test for $2 \mathrm{~h}$ in the inoculated media in the presence of the D7A inhibitor is given in Figure 9. 


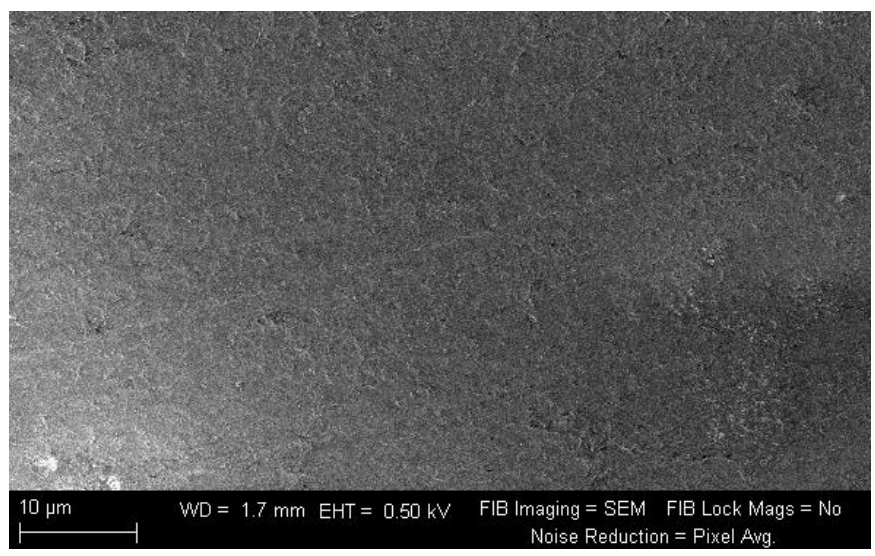

Figure 9. SEM image of the membrane entrance side after the hydrogen permeation test for $2 \mathrm{~h}$ in the inoculated media containing $190 \mathrm{mg} / \mathrm{L} \mathrm{H}_{2} \mathrm{~S}$ in the presence of the D7A inhibitor.

\subsubsection{Hydrogen diffusion flux at cathodic polarization of the membrane entrance side}

Like at $E_{\text {corr }}$, solutions with 3 days SRB development corresponding to their maximum vital ability were used (the $\mathrm{H}_{2} \mathrm{~S}$ concentration is $190 \mathrm{mg} / \mathrm{L}$ ). In the presence of $\mathrm{SRB}, i_{\mathrm{H}}$ increases 3-4 fold in comparison with a sterile solution with the same $\mathrm{H}_{2} \mathrm{~S}$ concentration. The effect of the DHA compounds on hydrogen diffusion flux through the membrane under conditions of cathodic polarization $\left(\Delta E_{\mathrm{c}}\right)$ of its entrance side is shown in Figure 10 $\left(\Delta E_{\mathrm{c}}=E_{\text {corr }}-E_{\text {cathodic }}\right)$. The bactericides under study decrease the hydrogen diffusion flux in the presence of SRB. Their action is analogous to the effect at $E_{\text {corr }}$ where the products containing a 1-phenyl-3-methylpyrazole group in the molecule are more effective, especially in the presence of $-\mathrm{Cl}$ and $-\mathrm{NO}_{2}$ substituents in the benzene ring. The efficiency of the hydrogen diffusion flux suppression by the inhibitors under study decreases with increasing $\Delta E_{\mathrm{c}}$.

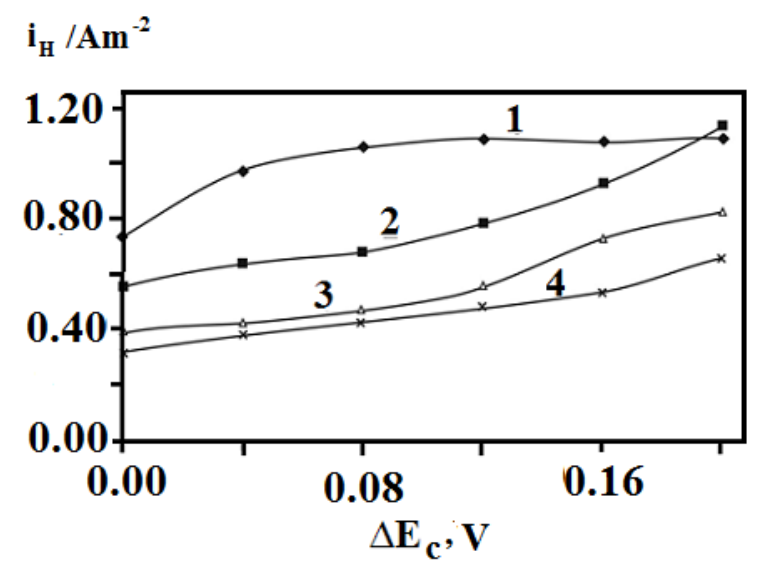

Figure 10. Influence of cathodic polarization $\left(\Delta E_{\mathrm{c}}\right)$ on the hydrogen diffusion flux $\left(i_{\mathrm{H}}\right)$ through a steel membrane in the inoculated Postgate medium containing $190 \mathrm{mg} / \mathrm{L} \mathrm{H}_{2} \mathrm{~S}$ without a bactericide (1) and with DHA compounds (20 mg/L): 2 - D1A; 3 - D6A; 4 - D7A. 


\subsubsection{Hydrogen diffusion flux at anodic polarization of the membrane entrance side}

Like in the sterile medium with $190 \mathrm{mg} / \mathrm{L} \mathrm{H}_{2} \mathrm{~S}$, the plot of $i_{\mathrm{H}} v s$. time passes through a maximum in the inoculated media, both in the absence and in the presence of the inhibitors $\left(\Delta E_{\mathrm{a}}=E_{\text {anodic }}-E_{\text {corr }}\right)$ (Figure 11). Hydrogen diffusion flux in the presence of SRB is 2-3 times higher than in the sterile medium with the same $\mathrm{H}_{2} \mathrm{~S}$ concentration. The effect of the bactericides increases in the order D1A $<$ D6A $<$ D7A, which coincides with the change in their effect at $E_{\text {corr }}$ and under cathodic polarization of the membrane entrance side. One can see that both the number of bacterial cells and $\mathrm{H}_{2} \mathrm{~S}$ production by SRB decrease in the same order (Table 2 and Figure 6).

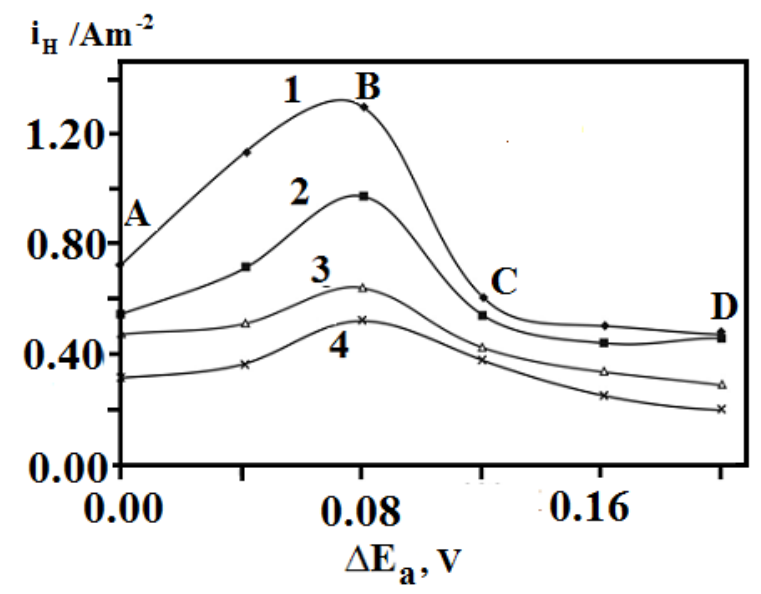

Figure 11. Influence of anodic polarization $\left(\Delta E_{\mathrm{a}}\right)$ on the hydrogen diffusion flux $\left(i_{\mathrm{H}}\right)$ through a steel membrane in the inoculated Postgate medium containing $190 \mathrm{mg} / \mathrm{L} \mathrm{H}_{2} \mathrm{~S}$ without a bactericide (1) and with DHA compounds (20 mg/L): 2 - D1A; 3 - D6A; 4 - D7A.

The presence of a maximum on the $i_{\mathrm{H}}=f\left(\Delta E_{\mathrm{a}}\right)$ plot was observed by many researches [33-36]. The explanation of the validity of its presence has been made a few years ago in [32].

3.4. Inhibition of steel corrosion by o, $o^{\prime}$-dihydroxyazo compounds in the presence of SRB

The highest corrosion rate of steel in the inoculated media is observed on the third day of bacteria development when the maximum concentration of $\mathrm{H}_{2} \mathrm{~S}$ is reached $(190 \mathrm{mg} / \mathrm{L})$. Its value is $0.28 \mathrm{~g} /\left(\mathrm{m}^{2} \mathrm{~h}\right)$. The bactericides under study slow down steel corrosion in the presence of SRB. However, the protective effect depends on the structure of their molecules. As stated above, the D1A and D3 compounds show a small bactericidal activity and their inhibitory effect is not high, either $(\mathrm{Z} \leq 40 \%)$. The DHA compounds whose molecules contain the 1-phenyl-3-methylpyrazole group are characterized by rather high protective effects (Table 3 ). As a rule, these substances show a high bactericidal activity, more effectively suppress $\mathrm{H}_{2} \mathrm{~S}$ production by $\mathrm{SRB}$, and substantially decrease the hydrogen diffusion flux through a steel membrane in the presence of SRB. 
Table 3. Protective effect $(Z, \%)$ of the DHA compounds against carbon steel corrosion in the inoculated Postgate medium in the stationary phase of SRB vital cycle

\begin{tabular}{ccccc}
\hline \multirow{2}{*}{ Bactericide } & \multicolumn{3}{c}{$\boldsymbol{Z , \%}$ at $\boldsymbol{C}_{\mathbf{D H A}}, \mathbf{m g} / \mathbf{L}$} \\
\cline { 2 - 5 } & $\mathbf{5}$ & $\mathbf{1 0}$ & $\mathbf{1 5}$ & $\mathbf{2 0}$ \\
\hline D3A & 43 & 47 & 49 & 51 \\
D4A & 30 & 35 & 40 & 43 \\
D5A & 46 & 57 & - & - \\
D6A & 50 & 51 & 61 & 64 \\
D7 & 59 & 72 & 80 & 85 \\
D7A & 72 & 80 & 85 & 90 \\
\hline
\end{tabular}

\section{Conclusion}

$o, o^{\prime}$ - Dihydroxyazo (DHA) compounds show bactericidal properties toward SRB in the Postgate media at sufficiently small concentrations $(5-20 \mathrm{mg} / \mathrm{L})$. Their bactericidal ability depends on the molecule structure. Incorporation of the NHCOOH substituent in one of the benzene rings of DHA compounds or replacement of the second benzene ring by a 1phenyl-3-methylpyrazole group increases the number of effects:

i. $\quad$ Decrease in the quantity of bacterial cells at all the phases of their vital cycle;

ii. Suppression of $\mathrm{H}_{2} \mathrm{~S}$ production by SRB;

iii. Decrease in hydrogen permeation into the steel membrane in the presence of SRB at the corrosion potential and under cathodic and anodic polarization;

iv. Inhibition of carbon steel corrosion in the bacterial medium.

The bactericide with the most favorable molecule structure (at $20 \mathrm{mg} / \mathrm{L}$ ) induces a drop in SRB quantity by $93 \%$, a decrease in biogenic $\mathrm{H}_{2} \mathrm{~S}$ production by $97 \%$, and a $2.5-$ fold suppression of hydrogen permeation into the metal in the stationary phase of bacterial vital cycle.

\section{Acknowledgements}

The authors acknowledge the Russian Department of Education and Science for financial support.

\section{References}

1. W. Lee, Z. Lewandowski, P.H. Nielsen and W.A. Hamilton, Biofouling, 1995, 8, 165.

2. R. Revie, Uhlig's Corrosion Handbook, Hoboken, N.J., Wiley, 2011.

3. M. de Romero, Z. Duque, O. de Rincón, O. Pérez, I. Araujo and A. Martinez, Corrosion, 2000, 56, 867. 
4. E.N. Kablov, O.V. Startsev, I.M. Medvedev and S.V. Panin, Korroz.: mater., zashch., 2013, no. 12, 6 (in Russian).

5. R. Zuo, Appl. Microbiol. Biotechnol., 2007, 76, 1245.

6. H. Castaneda and X.D. Benetton, Corros. Sci., 2008, 50, 1169.

7. N. Muthukumar, Electrochem. Commun., 2003, 5, 421.

8. S. Chongdar, G. Gunasekaran and P. Kumar, Electrochim. Acta, 2005, 50, 4655.

9. Z.H. Dong, W. Shi, H.M. Ruan and G.A. Zhang, Corros. Sci., 2011, 53, 2978.

10. Y.C. Chen, C.M. Lee, S.K. Yen and S.D. Chyou, Corros. Sci., 2007, 49, 3917.

11. H. Venzlaff, D. Enning, J. Srinivasan, K.J.J. Mayrhofer, A.W. Hassel, F. Widdel and M. Stratmann, Corros. Sci., 2013, 66, 88.

12. E. Ilhan-Sungur, N. Cansever and A. Cotuk, Corros. Sci., 2007, 49, 1097.

13. D.V. Belov, A.A. Kalinina, T.N. Sokolova, O.V. Kuzina and V.R. Kaptashov, Korroz.: mater., zashch., 2011, no. 7, 42 (in Russian).

14. R. Zuo, E. Kus, F. Mansfeld asnd T.K. Wood, Corros. Sci., 2005, 47, 279.

15. P. Cristiani, M.L. Carvalho, E. Guerrini, M. Daghio, C. Santoro and B. Li, Bioelectrochemistry, 2013, 92, 6.

16. L.E. Tsygankova, V.I. Vigdorovich, M.N. Esina, T.N. Nazina and E.V. Dubinskaya, Bioelectrochemistry, 2014, 97, 154.

17. N.O. San, H. Nazir and G. Donmez, Corros. Sci., 2011, 53, 2216.

18. V.I. Vigdorovich and S.A. Zakurnaev, Prot. Met. Phys. Chem. Surf., 2009, 45, 812.

19. V.I. Vigdorovich, L.E. Tsygankova and N.V. Shel, Surf. Interface Anal., 2010, 42, 626.

20. H. Ma, X. Cheng, G. Li, S. Chen, Z. Quan, S. Zhao and L. Niu, Corros. Sci., 2000, 42, 1669.

21. A.M. Zimer, E.C. Rios, P.C.D. Mendes, W.N. Gonçalves, O.M. Bruno, E.C. Pereira and L.H. Mascaro, Corros. Sci., 2011, 53, 3193.

22. A. Hernández-Espejel, M.A. Domínguez-Crespo, R. Cabrera-Sierra, C. RodríguezMeneses and E.M. Arce-Estrada, Corros. Sci., 2010, 52, 2258.

23. V.I. Vigdorovich and K.O. Strelnikova, Korroz.: mater., zashch., 2012, no. 4, 23 (in Russian).

24. V.I. Vigdorovich, L.E. Tsygankova and K.O. Strelnikova, Korroz.: mater., zashch., $2012, \mathbf{5}, 27$.

25. R.V. Kashkovskiy, Yu.I. Kuznetsov and L.P. Kazansky, Corros. Sci., 2012, 64, 126.

26. E.P. Rozanova, T.N. Nazina and A.S. Galushko, Microbiology (Eng. Tr.), 1988, 57, 514.

27. A.H. Rose, Chemical Microbiology, Springer Science+Business Media, New York, 1968.

28. J.R. Postgate, The sulphate reducing bacteria, 2nd. ed., Cambridge University Press, Cambridge, 1984.

29. M.A.V. Devanathan and Z. Stachurski, Proc. R. Soc., 270A, 1962, 90.

30. M.A.V. Devanathan and Z. Stachurski, J. Electrochem. Soc., 1964, 111, 619. 
31. N.V. Kardash and V.V. Batrakov, Zashch. Met., 1995, 31, 441 (in Russian).

32. M.V. Vigdorovich, V.I. Vigdorovich and L.E. Tsygankova, J. Electroanal. Chem., 2006, 596, 1.

33. A.P. Nazarov, A.P. Lisovsky and Yu.N. Mikhailovsky, Zashch. Met., 1996, 1996, 32, 478 (in Russian).

34. A.I. Marshakov, L.B. Maksaeva and Yu.N. Mikhailovsky, Zashch. Met., 1993, 29, 869.

35. V.I. Vigdorovich, L.E. Tsygankova and E.Yu. Kopylova, Rus. J. Elechtrochem., 2005, 41, 159.

36. L.E. Tsygankova,V.I. Vigdorovich and N.V. Shel, Int. J. Corros. Scale Inhib., 2014, 3, no. 4, 227. doi: 10.17675/2305-6894-2014-3-4-227-237 